\title{
The Dangers of Convictions Based on a Single Piece of Forensic Evidence
}

A Olaborede* and L Meintjes-van der Walt**

\section{P.E.R}

Pioneer in peer-reviewed,

open access online law publications

Author

Adebola Olaborede

Lirieka Meintjes-van der Walt

Affiliation

University of Fort Hare, South

Africa

Email

adebolaolaborede@gmail.com Imeintjes-vanderwalt@ufh.ac.za

Date Submission

25 March 2019

Date Revised

9 March 2020

Date Accepted

10 May 2020

Date published

20 May 2020

Editor Prof K Beiter

How to cite this article

Olaborede A and Meintjes-van der

Walt $L$ "The Dangers of

Convictions Based on a Single

Piece of Forensic Evidence" PER /

PELJ 2020(23) - DOI

http://dx.doi.org/10.17159/1727-

3781/2020/v23i0a6169

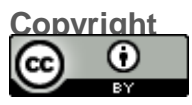

DOI

http://dx.doi.org/10.17159/1727-

3781/2020/v23i0a6169

\begin{abstract}
The overall goal of the criminal justice system is to ensure that perpetrators of crimes are duly punished and that victims of crimes are duly exonerated. As part of the effort to achieve this goal, the forensic disciplines have become very important in criminal investigations and prosecutions in identifying the guilty and in exonerating the innocent. There is a growing number of cases where people have been convicted based on a single piece of forensic evidence. However, some of the convictions have been found to be wrong, largely, due to the lack of adequate scientific validation of the forensic science methods. Some of these methods include latent fingerprint analysis, bite mark analysis, microscopic hair analysis and firearms identification. This article critically examines the application of forensic evidence in criminal prosecutions and highlights the dangers of convictions based on a single piece of forensic evidence. The findings of recent reports, such as, the National Academy of Sciences (NAS) 2009 Report and President's Council of Advisors on Science and Technology (PCAST) 2016 Report, confirm the critical role and broad scope of these forensic pattern-matching methods. The reports also indicate flaws that affect the accuracy of these methods, such as, inadequate scientific validation, coincidental results (erroneous match), human, laboratory and interpretive errors etc. Therefore, this article argues that the court should follow a cautionary approach when relying on a single piece of forensic evidence and that strong corroboration with other forms of evidence linking the accused to the crime should be required.
\end{abstract}

\section{Keywords}

Forensic evidence; wrongful conviction; expert witness; patternmatching methods; criminal justice system. 


\section{Introduction}

Forensic ${ }^{1}$ evidence refers to physical evidence that is obtained either at the scene of a crime or from the victim of a crime and analysed by using scientific methods and processes in a crime laboratory in order to produce scientifically based information that is then presented in court by an expert witness or as an expert's testimony ${ }^{2}$ in order to link the accused to the crime.

In this way forensic evidence contributes immensely to the criminal justice system. Despite these contributions, there is a growing number of cases in different jurisdictions where people have been convicted based on a single piece of forensic evidence. ${ }^{3}$ Some of the convictions have been found to be wrong, largely, due to the lack of adequate scientific validation of the forensic evidence. ${ }^{4}$

Adebola Olaborede. LLB (Nigeria) LLM (US) LLD (UFH). Post-Doctoral Research Fellow, Law, Science and Justice Research Niche Area, Nelson Mandela School of Law, Faculty of Law, University of Fort Hare, South Africa. Email: adebolaolaborede@gmail.com. ORCID: https://orcid.org/0000-0002-8510-5519.

Lirieka Meintjes-van der Walt. BJuris LLB (UPE) LLM (Rhodes) DJuris (Leiden). Adjunct Professor and Leader of the Law, Science and Justice Research Niche Area, Nelson Mandela School of Law, Faculty of Law, University of Fort Hare, South Africa. Email: Imeintjes-vanderwalt@ufh.ac.za. ORCID: https://orcid.org/0000-0001-75678957.

$1 \quad$ The word "forensic" is derived from the Latin term forensus which means of the forum. This is a public place where the ancient Roman senate discussed and debated on political and policy issues. It was also used as a court to resolve legal issues. The term "forensic science" has been defined "as the application of scientific or technical practices to the recognition, collection, analysis, and interpretation of evidence for criminal and civil law or regulatory issues. See also Meintjes-van der $\begin{array}{llllll}\text { Walt } 2006 & \text { SACJ } & 152-154 & \text { and } & \text { PCAST } & 2016\end{array}$ https://obamawhitehouse.archives.gov/sites/default/files/microsites/ostp/PCAST/pc ast_forensic_science_report_final.pdf 21.

2 Kaplan and Puracal 2018 Alb L Rev 899-900; NAS Strengthening Forensic Science 5; Bell et al $2018 \mathrm{http}: / /$ www.pnas.org/content/pnas/115/18/4541.full.pdf 4541-4544; Sangero and Halpert 2007 Jurimetrics $J 43$.

3 See, for example, Regina v Adams $19962 \mathrm{Cr}$ App R 467. Also see Sangero and Halpert 2007 Jurimetrics J 46 and Griffin 2001 Am U Int'l L Rev 1241-1308.

$4 \quad$ See, for example, Commonwealth $v$ Cowans 756 NE 2D 622 (Mass App Ct 2001) and State $v$ Krone $897 \mathrm{P} \mathrm{2d} 621$ (Ariz 1995). See also the reports from the US National Registry of Exonerations (NRE) and the US Innocence Project which show a record of more than 2,270 wrongful convictions since 1989. The reports also confirmed that unvalidated or improper forensic methods have contributed to the conviction of innocent persons. US Innocence Project 2016 https://www.innocenceproject.org/wpcontent/uploads/2016/02/DNA_Exonerations_ Forensic_Science.pdf; US Innocence Project date unknown https://www.innocenceproject.org/causes/misapplication-forensic-science/; Mnookin 2018 https://ssrn.com/abstract=3300354 99-118. 
Forensic evidence is categorised as circumstantial evidence as it relies on inferences to connect it to a conclusion of fact. ${ }^{5}$ This involves a witness, ${ }^{6}$ in this case, a forensic expert witness (examiner) analysing and laying the scientific foundation for the forensic evidence when it is taken into consideration in court. ${ }^{7}$ The expert witness gives testimony in court based on his or her acquired skills and expertise on the application of forensic science methods/techniques to the evidence obtained at a crime scene. ${ }^{8}$

It is a general rule of law that a person can be convicted on the evidence of a single witness. For example, section 208 of the South African Criminal Procedure Act 51 of 1977 provides that: "An accused may be convicted of any offence on the single evidence of any competent witness". However, it is trite that "...the evidence of a single witness should be approached with caution, and his or her merits being weighed against factors which militate against his or her credibility". ${ }^{9}$ It is also trite that "a court should not easily convict upon the evidence of a single witness unless it is substantially satisfactory in all material respects or unless it is corroborated". ${ }^{10}$ By corroboration is meant "other evidence which supports the evidence of the single witness and which detracts from the evidence of the accused and renders it less probable with regard to one or more of the issues in dispute". ${ }^{11}$

The need for caution may also be increased by other factors such as the state's failure to adduce real evidence which should have been available. ${ }^{12}$ This is pointed out in $S v$ Msane where it was stated that:

The tendency of prosecutors to take short-cuts by not adducing all the available evidence should be discouraged by magistrates. The feckless presentation of the case for the prosecution is subversive of proper criminal justice. It creates alike the risk of the acquittal of guilty persons and the conviction of innocent ones. ${ }^{13}$

Zeffertt and Paizes South African Law of Evidence 101-102, 172.

A witness is a person who gives evidence in court either for the prosecution or the defence. See Hornby Oxford Advanced Learner's Dictionary 1729.

Kaplan and Puracal 2018 Alb L Rev 899-900.

$8 \quad$ Schwikkard and Van der Merwe Principles of Evidence 102, 594; Kaplan and Puracal 2018 Alb L Rev 899-900.

$9 \quad$ See $S v$ Stevens 20051 All SA 1 (SCA) para 17. See also S v Sauls 19813 SA 172 (A) 180E-G where Diemont JA established the approach to the "cautionary rule".

10 See S v Ganie 19674 SA 203 (N) 206H and S v Artman 19683 SA 339 (A) 341 as quoted in $B \vee S 2016$ ZAFSHC 100 (12 May 2016) 55-58.

$11 \quad R v W 19493$ SA 773 (AD) 778/9 as quoted in Cele $v$ S 2010 ZAKZPHC 26 (25 May 2010).

$12 \quad$ See $S$ v Msane 19774 SA $758(\mathrm{~N})$.

$13 \quad S$ v Msane 19774 SA 758 (N) 759C-E. See also Nkuna $v$ S 2018 ZALMPPHC 21 (11 May 2018); S v Sauls 19813 SA 172 (A) 180 C-H. 
The question of whether a single piece of forensic evidence is enough to convict an accused person, lies at the heart of this article. Forensic evidence implies the potential dangers of the wrongful conviction of an innocent person ${ }^{14}$ based on evidence that is probabilistic in nature and which has the possibility of coincidental results (random match), the possibility of laboratory errors and interpretive errors. ${ }^{15}$

The aim of this article is critically to examine the application of forensic evidence in criminal prosecutions and to pay particular attention to the dangers of convictions based on a single piece of forensic evidence. The article focuses on forensic pattern-matching methods, specifically latent fingerprint analysis, bite mark analysis, microscopic hair analysis and firearms identification. These methods are referred to as "forensic featurecomparison methods"16 by the President's Council of Advisors on Science and Technology (PCAST). ${ }^{17}$ The focus in this article on these methods is prompted by the fact that they are forensic tools commonly used during

$14 \quad$ According to Oxford Advanced Learner's Dictionary innocent means a person not guilty of a crime and "wrongful" is a term often used in a legal situation, it means for something to be mistaken, incorrect or inaccurate. Therefore, wrongful conviction is the wrongful act of finding a person guilty of a crime in court. Griffin also defines the terms "innocent" and "wrongful conviction" to mean "someone who is neither factually nor legally responsible for a charged crime" and "a conviction that is both factually and legally inaccurate". This definition of terms is intended for better understanding of the scope of the dangers of conviction based on a single piece of evidence. See Hornby Oxford Advanced Learner's Dictionary 327, 787, 1744 and Griffin 2001 Am U Int'I L Rev 1243 fn 2.

$15 \quad$ Sangero and Halpert 2007 Jurimetrics $J 55$.

16 Forensic feature-comparison methods refer to "the wide variety of methods that aim to determine whether an evidentiary sample (e.g. from a crime scene) is or is not associated with a potential source sample (e.g. from a suspect) based on the presence of similar patterns, impressions, features or characteristics in the sample and the source". See PCAST 2016 https://obamawhitehouse. archives.gov/sites/default/files/microsites/ostp/PCAST/pcast_forensic_science_rep ort_final.pdf 23 and Kaplan and Puracal 2018 Alb L Rev 898.

17 The terms "matching" and "comparison" are two words often used interchangeably especially in the context of the identification and individualisation of a particular individual and a piece of forensic evidence. Also, important to note that in forensic science identification involves comparing "a questioned item of evidence to an exemplar from a known source and judge whether they appear so alike that they can be said to match". It also involves assessing "the meaning of that reported match: What is the probability that the questioned and the known originated from the same source?" Individualisation on the other hand "implies uniqueness". It "refers to absolute specificity and absolute identification". The uniqueness of a particular sample simply shows that the characteristics of the sample is distinct from others. For further discussion, see Saks and Koehler 2008 Vand L Rev 199, 205; Meintjesvan der Walt 2006 SACJ 152-153; and Kaye 2010 Brook L Rev 1165. 
criminal investigations and prosecutions. ${ }^{18}$ These forensic methods belong to the "same broad scientific discipline" which involves forensic experts "measuring and comparing features" to identify the accused person. ${ }^{19}$ In addition to this, some of the forensic experts' testimony based on using these forensic science methods, have been linked to cases of wrongful conviction of innocent persons. ${ }^{20}$ Furthermore, there is an increased concern regarding the lack of adequate standard(s) for the scientific validity and reliability ${ }^{21}$ of pattern-matching methods, as this can result in the problem of a high possibility of error in the interpretation of evidence, threat of bias and absence of reliable operational procedures. ${ }^{22}$ By scientific validity and reliability, is meant that each forensic pattern-matching method must have been subjected to empirical testing that provides valid estimates of the error rate of each method as well as of the possibility of an accurate match. ${ }^{23}$

This article does not consider DNA analysis which is recognised as the "gold standard" for forensic feature-comparison methods. ${ }^{24}$ DNA analysis is recognised for having a higher capacity to support conclusions about individualisation ${ }^{25}$ which refers to matching forensic evidence to a particular

18 PCAST $2016 \mathrm{https}: / /$ obamawhitehouse.archives.gov/sites/default/files/microsites/ ostp/PCAST/pcast_forensic_science_report_final.pdf 23; Mnookin 2018 https://ssrn.com/abstract=3300354 102.

19 PCAST $2016 \mathrm{https}: / /$ obamawhitehouse.archives.gov/sites/default/files/microsites/ ostp/PCAST/pcast_forensic_science_report_final.pdf 21, 23.

See, for example, Commonwealth v Cowans 756 NE 2D 622 (Mass App Ct 2001) where fingerprint identification evidence contributed to the wrongful conviction of the accused person, but he was later exonerated by DNA evidence and State $v$ Krone 897 P 2d 621 (Ariz 1995) where bitemark analysis led to the wrongful conviction of the accused person, but DNA analysis exonerated the accused after ten years. Also see Garrett and Neufeld 2009 Va L Rev 1-97. (The study found that there was a large number of cases where forensic experts provided invalid testimony at trial this is regarding testimony with conclusions misstating empirical data or wholly unsupported by empirical data).

21 The term validity refers "to the ability of a test procedure to measure what it is supposed to measure [that is] its accuracy", while reliability refers "to whether the same results are obtained in each instance in which the test is performed [that is] its consistency". See Giannelli 1980 Colum L Rev 1201 fn 20.

PCAST 2016 https://obamawhitehouse.archives.gov/sites/default/files/microsites/ ostp/PCAST/pcast_forensic_science_report_final.pdf 23; NAS Strengthening Forensic Science 87; Kaplan and Puracal 2018 Alb L Rev 904-905.

PCAST 2016 https://obamawhitehouse.archives.gov/sites/default/files/microsites/ ostp/PCAST/pcast_forensic_science_report_final.pdf 46. PCAST $2016 \mathrm{https}: / /$ obamawhitehouse.archives.gov/sites/default/files/microsites/ ostp/PCAST/pcast_forensic_science_report_final.pdf 26; Kaplan and Puracal 2018 Alb L Rev 904-905.

The National Academy of Sciences notes that: "With the exception of nuclear DNA analysis, however, no forensic method has been rigorously shown to have the capacity to consistently, and with a high degree of certainty, demonstrate a connection between evidence and a specific individual or source". See NAS 
accused person or exonerating persons that were wrongfully convicted of a crime. ${ }^{26}$ It is important to note that this is not to state that DNA analysis is error-free, ${ }^{27}$ but rather to state that when compared to the other forensic feature-comparison methods, DNA analysis has a higher standard for the validity and reliability of evidence.

This article considers the development and interpretation of the courts regarding the admissibility of forensic evidence in jurisdictions such as the United States, England and Wales ${ }^{28}$ and South Africa. The interest in these jurisdictions is because they operate an adversarial system which involves the prosecution and the defence conducting vigorous cross-examination, presenting contrary evidence, and careful instruction regarding the burden of proof in criminal cases. ${ }^{29}$ The United States offers a broad picture of forensic science with a large number of cases that have used different forensic pattern-comparison methods. For example, the case of Frye $v$ United States ${ }^{30}$ and Daubert $v$ Merrell Dow Pharmaceuticals, Inc ${ }^{31}$ provide landmark decisions on the development and interpretation of standards pertaining to the admissibility of scientific evidence..$^{32}$ Some of the judicial decisions have influenced the law and standards for scientific evidence in other jurisdictions, such as England and South Africa. ${ }^{33}$ Also, the interest in England is mainly because South African law draws much of its history from the English law. ${ }^{34}$ South African law of evidence is based broadly on the English system and therefore expert evidence is admissible whenever it is relevant. ${ }^{35}$ This is different from the United States approach where the

Strengthening Forensic Science 7. Also, some of the reports that have highlighted the significance of DNA analysis include: PCAST 2016 https://obamawhitehouse.archives.gov/sites/default/files/microsites/ostp/PCAST/pc ast_forensic_science_report_final.pdf 26; Connors et al 1996 https://www.ncjrs.gov/pdffiles/dnaevid.pdf; NAS Strengthening Forensic Science 7, 87.

NAS Strengthening Forensic Science 7 and Connors et al 1996 https://www.ncjrs.gov/pdffiles/dnaevid.pdf.

Elster 2017 https://daily.jstor.org/forensic-dna-evidence-can-lead-wrongfulconvictions/ (points out that DNA evidence sometimes can be misused or misunderstood which can lead to a miscarriage of justice). When the rest of the text refers to England it implies England and Wales. NAS Strengthening Forensic Science 10; Griffin 2001 Am U Int'l L Rev 1244; Langbein Origin of Adversary Criminal Trial 1-3.

$30 \quad$ Frye $v$ United States 293 F 1013 (DC Cir 1923).

31 Daubert v Merrell Dow Pharmaceuticals, Inc 1993509 US 579 (hereafter Daubert v Merrell Dow Pharmaceuticals, Inc). NAS Strengthening Forensic Science 88.

Bernstein 1996 Yale J Int'l L 125-126.

Zeffertt and Paizes South African Law of Evidence 3-14.

Nduna v S 2010 ZASCA 120 (30 September 2010), the court stated that evidence is only admissible if relevant to an issue in a case; S v Gokool 19653 SA 461 (N) 457G. 
expert evidence must not only be relevant, but also reliable. ${ }^{36}$ However, as the United States also falls within the Anglo-American family of jurisdictions, worthwhile comparative lessons can be learnt from its jurisprudence regarding the validity and reliability of forensic feature comparison evidence.

This article proceeds as follows: part II provides the legal justification surrounding the burden of proof, the admissibility of forensic expert evidence and the evaluation of such evidence in determining the weight that should be attached to it. Part III provides a general overview of the forensic feature-comparison methods: latent fingerprint analysis, bite mark analysis, hair analysis and firearm identification and highlights areas of shortcomings when using the method. In part IV the dangers of conviction based on a single piece of forensic evidence is briefly considered.

\title{
2 The admissibility of forensic expert evidence in criminal cases
}

The law of evidence and the adversarial criminal procedure system regulate criminal proceedings in common law jurisdictions. ${ }^{37}$ In criminal cases, the general procedural rule of law is that the burden of proof rests on the prosecution and the standard of proof of the guilt of the accused must be "beyond reasonable doubt" (using all available evidence including forensic evidence).$^{38}$ This is confirmed by Sachs $J$ in the case of $S v$ Baloyi in stating that:

\begin{abstract}
The requirement that the state [prosecution] must prove guilt beyond a reasonable doubt has been called the golden thread running through the criminal law, and a prime instrument for reducing the risk of convictions based on factual error. ${ }^{39}$
\end{abstract}

The success or failure of proving the guilt of the accused beyond reasonable doubt largely depends on the evidence, including the expert testimony, presented in court and the admissibility thereof. The standard for the admissibility of expert testimony derived from scientific methods or techniques, originated in Frye $v$ United States where the court established

See also s 210 of the Criminal Procedure Act 51 of 1977 which provides that irrelevant evidence is inadmissible.

See Part 2: Admissibility of Forensic Expert Evidence in Criminal Cases for more discussion. Daubert v Merrell Dow Pharmaceuticals, Inc, where the court ruled that trial judges are to make sure that expert testimony is not only relevant but reliable. Griffin 2001 Am U Int'l L Rev 1241.

Schwikkard and Van der Merwe Principles of Evidence 17.

$S$ v Baloyi 20002 SA 425 (CC) para 15. Also see Green v R 1971126 CLR 28 3233 cited in The Queen v Dookheea 2017 HCA 36; 91 ALJR 960 para 20. 
the general acceptance test. ${ }^{40}$ The test implies that an expert witness must show that his or her testimony is generally accepted in the relevant scientific community. ${ }^{41}$ This test became the dominant standard ${ }^{42}$ and precedent for the admissibility of scientific testimony. ${ }^{43}$ Although the general acceptance test was embraced by some courts, ${ }^{44}$ it, however, had a number of shortcomings, especially relating to the vagueness of the scope of the test and its limited scientific scrutiny. ${ }^{45}$

In 1975, the Federal Rule of Evidence was enacted to guide criminal and civil litigations in Federal courts. ${ }^{46}$ Rule 702 provides that:

If scientific, technical, or other specialized knowledge will assist the trier of fact to understand the evidence or to determine a fact in issue, a witness qualified as an expert by knowledge, skill, experience, training, or education, may testify thereto in the form of an opinion or otherwise. ${ }^{47}$

40 Frye $v$ United States 293 F 1013 (DC Cir 1923) cited in NAS Strengthening Forensic Science 88; PCAST 2016 https://obamawhitehouse.archives.gov/sites/ default/files/microsites/ostp/PCAST/pcast_forensic_science_report_final.pdf 40 . The court considered the admissibility of a deception test that measured systolic blood pressure which an expert witness sought to introduce as evidence on behalf of the defendant to establish his innocence in the murder trial. The court rejected the evidence, stating that: "...while courts will go a long way in admitting expert testimony deduced from a well-recognized scientific principle or discovery, the thing from which the deduction is made must be sufficiently established to have gained general acceptance in the particular field in which it belongs". The court ruled that the deception test had "not yet gained such standing and scientific recognition among physiological and psychological authorities". Cooley and Oberfield 2013 Tulsa L Rev 285, 287.

Giannelli 1980 Colum L Rev 1207.

NAS Strengthening Forensic Science 88-89. See also United States v Scheffer 1998 523 US 303, No 96-1133 cited in Newton DNA Evidence and Forensic Science 75, where the defendant sought to present evidence from a polygraph testing, but the court ruled that "polygraph evidence is not relevant because polygraph testing had still not attained the necessary level of [general] acceptance in the scientific community".

44 The support for the general acceptance test was mainly because the test assures of the opinion of well-qualified experts within the particular field of the scientific method; it promotes a degree of uniformity in judicial decision and eliminates possible timeconsuming hearings on the validity of scientific methods. See Giannelli 1980 Colum L Rev 1207.

Giannelli notes that the courts discovered that there was a need to determine the parameters of the Frye test in terms of "who must find the procedure acceptable, they [the courts] must define exactly what must be accepted, and they [the courts] must determine what methods will be used to establish general acceptance". See Giannelli 1980 Colum L Rev 1208; Meintjes-van der Walt 2006 SACJ 154. Also see United States v William $1978583 \mathrm{~F} 2 \mathrm{~d} 1194$ para 28.

46 PCAST 2016 https://obamawhitehouse.archives.gov/sites/default/files/microsites/ ostp/PCAST/pcast_forensic_science_report_final.pdf 40; NAS Strengthening Forensic Science 89.

NAS Strengthening Forensic Science 89. 
The standard in Rule 702 contrasts with Frye's general acceptance test and this raised questions regarding the acceptable standard for admissibility of forensic expert evidence derived from scientific methods or techniques. Questions in this regard were clarified in Daubert $v$ Merrell Dow Pharmaceuticals, Inc when the Supreme Court overruled Frye's general acceptance test and ruled that under Rule 702 "a trial judge must ensure that any and all scientific testimony or evidence admitted is not only relevant but reliable". ${ }^{48}$ The court must make "a preliminary assessment of whether the reasoning or methodology underlying the testimony ... properly can be applied to the facts in issue" and whether that reasoning or methodology "rests on a reliable foundation". ${ }^{49}$ This means that "the subject of an expert's testimony should be 'scientific knowledge', so that evidentiary reliability will be based upon scientific validity". ${ }^{0}$ Also, the trial judges must act as "gatekeepers" and confirm the expert's testimony to ensure that it rests on a reliable foundation. ${ }^{51}$ In doing so, the judges must consider five factors in evaluating the validity of an underlying scientific method. ${ }^{52}$ The factors include:

(i) whether a theory or technique can be (and has been) tested;

(ii) whether the theory or technique has been subjected to peer review and publication;

(iii) the known or potential rate of error of a particular scientific technique;

48 Daubert $v$ Merrell Dow Pharmaceuticals, Inc is a civil case brought to court by two children born with birth defects and their parents against Merrell Dow Pharmaceuticals alleging that the children had birth defects as a result of their mothers' prenatal ingestion of Benedictin a drug marketed by Merrell Dow. At the trial, Merrell Dow called an expert witness who testified that Benedictin has been subjected to intensive trials with human and that no evidence existed for teratogenic effects of the in humans. The plaintiffs (Daubert) called eight witnesses who testified on animal studies and comparisons of the chemical structure of Benedictin. They concluded that the drug could cause birth defects. The trial court held that the plaintiff's expert testimony was inadmissible because the scientific evidence was not sufficiently established to be generally accepted in the field to which it belonged. The Court of Appeal affirmed the decision of the trial court citing the Frye case. At the Supreme Court, the trial court's decision was reversed. The Supreme Court held that the trial court had applied the wrong standard to assess the admissibility of the plaintiff's expert testimony. The court ruled that the Federal Rules of Evidence applied and supersedes the Frye test as the standard for admissibility. See NAS Strengthening Forensic Science 90. Chandler 2013-2014 Buff Pub Int LJ 44.

NAS Strengthening Forensic Science 90.

51 PCAST $2016 \mathrm{https}: / /$ obamawhitehouse.archives.gov/sites/default/files/microsites/ ostp/PCAST/pcast_forensic_science_report_final.pdf 41 .

52 PCAST 2016 https://obamawhitehouse.archives.gov/sites/default/files/microsites/ ostp/PCAST/pcast_forensic_science_report_final.pdf 41. 
(iv) the existence and maintenance of standards controlling the technique's operation; and

(v) a scientific technique's degree of acceptance within a relevant scientific community. ${ }^{53}$

In Kumho Tire Co v Carmichael the court noted that these Daubert factors do not constitute a definitive checklist or test and the law grants the court broad latitude to determine whether or not they are "reasonable measures of reliability". ${ }^{54}$ Following the decision in the Daubert case, in 2000, the Federal Rule of Evidence 702 was amended and provides that:

If scientific, technical, or other specialised knowledge will assist the trier of fact to understand the evidence or to determine a fact in issue, a witness who is qualified as an expert by knowledge, skill, experience, training, or education may testify in the form of an opinion or otherwise if:

(1) the testimony is based on sufficient facts or data;

(2) the testimony is the product of reliable principles and methods; and

(3) the expert has reliably applied the principles and methods to the facts of the case..$^{55}$

By this amendment, courts are compelled to question the empirical research foundation of all expert testimony presented in court and to "exclude opinions which are connected to existing data only by the ipse dixit of the expert". ${ }^{56}$

The standards for the admissibility of forensic evidence specifically in the Daubert case and the Federal Rule of Evidence 702 have influenced the reasoning of the courts in the United States and other jurisdictions. The South African approach to the admissibility of an expert witness's testimony is different. The South African law of evidence, which governs expert testimony, is broadly based on the English system and therefore expert evidence (including evidence based on pattern-matching forensic methods) will be admissible whenever it is relevant and if it can be of assistance to the court. ${ }^{57}$ Section 210 of the South African Criminal Procedure Act 51 of

53 PCAST 2016 https://obamawhitehouse.archives.gov/sites/default/files/microsites/ ostp/PCAST/pcast_forensic_science_report_final.pdf 41.

$54 \quad$ Kumho Tire Co v Carmichael 1999526 US 137; NAS Strengthening Forensic Science 10-11.

55 Cooley and Oberfield 2013 Tulsa L Rev 288-289.

56 Cooley and Oberfield 2013 Tulsa L Rev 288-289. The term "ipse dixit" simply means an assertion made by an expert without any proof.

57 See Nduna v S 2010 ZASCA 120 (30 September 2010), the court stated that evidence is only admissible if relevant to an issue in a case; $S v$ Gokool 19653 SA 461 (N) 457G. 
1977 also provides that: "No evidence as to any fact, matter or thing shall be admissible which is irrelevant or immaterial and which cannot conduce to prove or disprove any point or fact at issue in criminal proceedings". Therefore, reliability is not considered as a prerequisite for the admissibility of forensic evidence in South Africa. ${ }^{58}$ However, Edmond and Meintjes-van der Walt point out that the reliability of evidence "will be explored effectively during trial, through cross-examination and/or by contrary (ie rebuttal) expert evidence that may be adduced by another party"..$^{59}$ In addition to this, Schwikkard and Van der Merwe explain that the court must be satisfied that:

(a) the [expert] witness not only has specialist knowledge, training, skill or experience but can furthermore, on account of these attributes or qualities, assist the court in deciding the issues; (b) that the witness is indeed an expert for the purpose for which he is called upon to express an opinion; (c) that the witness does not or will not express an opinion on hypothetical facts, that is facts which have no bearing on the case or which cannot be reconciled with all the other evidence in the case..$^{60}$

The lack of a reliability test in South Africa, contrasts with the standards in the Daubert case which are designed to ensure greater caution. ${ }^{61}$ Despite the fact that the standards are guidelines subject to the discretion of the courts, regarding the weight (reliability) that should be attached to the forensic evidence, specifically as far as forensic pattern-matching methods are concerned, the South African legal system has much to learn from the admissibility criteria set out in Daubert.

\subsection{The scientific validity and reliability of forensic evidence}

The use of forensic science, specifically in criminal prosecutions, according to the PCAST Report, require that a high standard be satisfied. ${ }^{62}$ The established standard in the Daubert case and Rule 702 of the Federal Rules of Evidence is that expert testimony should be based, among other things on the application of reliable principles and methods that are scientifically valid. 63

According to Giannelli, the reliability of forensic (scientific) evidence depends on three factors:

\footnotetext{
$58 \quad$ Edmond and Meintjes-van der Walt 2014 SALJ 113.

$59 \quad$ Edmond and Meintjes-van der Walt 2014 SALJ 113.

60 Schwikkard and Van der Merwe Principles of Evidence 102.

61 Sangero 2018 Ga St UL Rev 1203.

62 PCAST 2016 https://obamawhitehouse.archives.gov/sites/default/files/microsites/ ostp/PCAST/pcast_forensic_science_report_final.pdf 4, 21.

63 PCAST $2016 \mathrm{https}$ ://obamawhitehouse.archives.gov/sites/default/files/microsites/ ostp/PCAST/pcast_forensic_science_report_final.pdf 4, 21.
} 
(i) the validity of the underlying principle

(ii) the validity of the technique applying that principle

(iii) the proper application of the technique on a particular occasion (this is regarding an examination of the functioning of any instrument employed in the technique to ensure the accuracy of results; adherence to the correct procedures; qualification of experts conducting the procedure and/or interpreting the results). ${ }^{64}$

Giannelli rightly notes that the first two factors are critical considerations for the admissibility of evidence derived from a novel scientific principle and technique. ${ }^{65}$ This is because once forensic or scientific evidence is established as reliable, the court thereafter may take judicial notice of the validity of the principles and techniques. ${ }^{66}$

The PCAST Report, which is a more recent study, provides a broader context of the standards for scientific validity and reliability, including the three factors for the reliability of scientific evidence discussed above. ${ }^{67}$ Scientific validity is described as a method [principle or technique] which "has shown, based on empirical studies, to be reliable with levels of repeatability, reproducibility, and accuracy that are appropriate to the intended application."68 In other words, a method (such as fingerprint identification or bitemark analysis) is valid if it can, by means of empirical testing distinguish between a guilty person and an innocent person. ${ }^{69}$ Scientific reliability, on the other hand, means consistency of a method, in terms of different experts obtaining the same result each time a method is performed in a different case. ${ }^{70}$

Most importantly, the accuracy of a forensic method has to be measured based on appropriate empirical testing. Therefore, an expert's conclusions that two samples are similar or dissimilar without valid estimates of accuracy, is scientifically meaningless. ${ }^{71}$ Such conclusions have "no

Giannelli 1980 Colum L Rev 1197-1250; Sangero 2018 Ga St UL Rev 1134; Cooley and Oberfield 2013 Tulsa L Rev 288-289; Mnookin 2018 https://ssrn.com/abstract=3300354 99-118.

Giannelli 1980 Colum L Rev 1201; Chandler 2013-2014 Buff Pub Int LJ 46. Giannelli 1980 Colum L Rev 1202; Chandler 2013-2014 Buff Pub Int LJ 46.

PCAST 2016 https://obamawhitehouse.archives.gov/sites/default/files/microsites/ ostp/PCAST/pcast_forensic_science_report_final.pdf 4, 47-48.

PCAST 2016 https://obamawhitehouse.archives.gov/sites/default/files/microsites/ ostp/PCAST/pcast_forensic_science_report_final.pdf 48.

Sangero 2018 Ga St UL Rev 1134.

Sangero 2018 Ga St UL Rev 1134.

PCAST 2016 https://obamawhitehouse.archives.gov/sites/default/files/microsites/ ostp/PCAST/pcast_forensic_science_report_final.pdf 46. 
probative value and considerable potential for prejudicial impact."72 Also, the appropriate empirical testing employed by an expert cannot be substituted with training, personal experiences, professional practices or inference from casework. ${ }^{73}$

\section{A brief overview of some forensic pattern-matching methods}

\subsection{Latent fingerprint analysis}

Latent fingerprints are said to be "unique patterns" made from "a complete or partial friction-ridge impression" on the fingers and thumbs of a person. ${ }^{74}$ During criminal investigations, "a residue of oily secretions that corresponds to the ridges on the fingers..." are usually found on surfaces, such as, a doorknob, a drinking glass or a computer keyboard etc at the crime scene. ${ }^{75}$

A latent print examiner often uses the "conventional procedure" known as the ACE-V (Analysis, Comparison, Evaluation and Verification) to examine the impression of friction ridge of the unknown latent print obtained at the crime scene and the fingerprint of the accused. ${ }^{76}$ The conclusions with regard to whether or not a similarity exists between the prints are presented in court as the examiner's testimony.

72 PCAST $2016 \quad$ https://obamawhitehouse.archives.gov/sites/default/files/ microsites/ostp/PCAST/pcast_forensic_science_report_final.pdf 46 .

73 PCAST 2016 https://obamawhitehouse.archives.gov/sites/default/files/microsites/ ostp/PCAST/pcast_forensic_science_report_final.pdf 46, 53.

74 Newton DNA Evidence and Forensic Science 16-19; Champod and Chamberlain "Fingerprints" 57-58; PCAST 2016 https://obamawhitehouse.archives.gov/sites/ default/files/microsites/ostp/PCAST/pcast_forensic_science_report_final.pdf 87103; National Forensic Science Technology Center date unknown http://www.forensicsciencesimplified.org/prints/Fingerprints.pdf.

75 Newton DNA Evidence and Forensic Science 16. According to the National Forensic Science Technology Center, a common method for "discovering and collecting latent prints is by dusting a smooth or nonporous surface with fingerprint powder (black granular, aluminium flake, black magnet etc). If any prints appear, they are photographed... and then lifted from the surface with clear adhesive tape. The lifting tape is then placed in a latent lift card to preserve the print". See National Forensic Science Technology Center date unknown http://www.forensicsciencesimplified.org/ prints/Fingerprints.pdf 1-6.

76 The fingerprints are usually taken by an enforcement officer ie police officer using an ink pad and a white identification card or Automated Fingerprint Identification System (IAFIS). See Kaye et al 2012 https://commons.erau.edu/publication/1222/ 18 and Budowle, Buscaglia and Swartz Perlman 2006 https://archives.fbi.gov/archives/about-us/lab/forensic-sciencecommunications/fsc/jan2006/research/2006_01_research02.htm. 
The latent print identification method is based on the premise that no two people, including identical twins, have the same fingerprint patterns. ${ }^{77}$ This implies that the friction ridge pattern of a latent print left at a crime scene should match to the fingerprint of the person who committed the crime. ${ }^{78}$ The friction ridge on the fingers are said to be unique and permanent. ${ }^{79} \mathrm{By}$ the assumption of uniqueness and permanence, latent print identification is argued to be a relatively reliable forensic pattern-matching method. ${ }^{80}$

The latent print method is well- established in the United States and it has been admitted by the courts for many years. ${ }^{81}$ It is a well-recognised forensic method and is also used in criminal cases in South Africa. The court in $S v$ Mbatha notes that the latent fingerprint testimony must be presented by an expert witness in criminal proceedings. ${ }^{82}$ The court in $S v$ Gumede specified the duty of courts when assessing evidence of fingerprint experts as follows:

The courts must, first be satisfied that the witness is competent to give evidence, that he is properly trained and has sufficient experience. Secondly, it must be satisfied as to the origin of the sets of fingerprints that are being compared, meaning the set that was found at the scene of the crime and the set of the accused. Thirdly, it must be satisfied that the expert conducted a proper enquiry in comparing the two sets and that he is capable of referring to sufficient points of similarity. ${ }^{83}$

In order to establish the guilt of the accused and for the courts to be sufficiently satisfied with the identification of the accused, it is common practice for the South African courts to accept at least seven points of similarity as sufficient evidence. ${ }^{84}$ It should be noted that there is no general consensus or standard with regard to matching points of similarities. While

77 Newton DNA Evidence and Forensic Science 16; PCAST 2016 https://obamawhitehouse.archives.gov/sites/default/files/microsites/ostp/PCAST/pc ast_forensic_science_report_final.pdf 88; Kaplan and Puracal 2018 Alb L Rev 911 and National Forensic Science Technology Center date unknown http://www.forensicsciencesimplified.org/prints/Fingerprints.pdf 1-6.

78 Kaplan and Puracal 2018 Alb L Rev 911.

79 Budowle, Buscaglia and Swartz Perlman 2006 https://archives. fbi.gov/archives/about-us/lab/forensic-sciencecommunications/fsc/jan2006/research/2006_01_research02.htm. Cole 2006 Golden Gate UL Rev 39-41. Also see NAS Strengthening Forensic Science 43, 140-142 and Kaplan and Puracal 2018 Alb L Rev 911.

81 Mnookin 2003 https://issues.org/mnookin/ 1 and Koehler 2008 Hastings LJ 1086.

82 See $S$ v Mbatha 2018 ZAGPJHC 502 (13 August 2018) para 64.

83 See $S$ v Gumede 19824 SA 561 (T) cited in $S$ v Mbatha 2018 ZAGPJHC 502 (13 August 2018) para 64.

$84 \quad$ See $S$ v Nala 19654 SA 360 (A) cited in S v Mbatha 2018 ZAGPJHC 502 (13 August 2018) para 64. Also see S v Gumede 19824 SA 561 (T); S v Nyathe 19882 SA 211 (O) (where the court in both cases accepted that seven points of similarity is sufficient to prove identity). 
some countries adopt a point-counting method, some others have rejected this method for a more holistic approach. ${ }^{85}$

Although latent fingerprint analysis has been recognised as a relatively reliable forensic method, it, however, has a number of shortcomings. Firstly, there is a lack of sufficient empirical studies conclusively to establish the uniqueness of the fingerprints. ${ }^{86}$ According to the NAS Report:

Uniqueness does not guarantee that prints from two different people are always sufficiently different that they cannot be confused, or that two impressions made by the same finger will also be sufficiently similar to be discerned as coming from the same source..$^{87}$

Meintjes-van der Walt equally notes that with fingerprint evidence there is no testing conducted that shows the statistical significance of a match (like DNA testing) to establish the probability of two fingerprints being identical. ${ }^{88}$ The PCAST Report found that although fingerprint comparison evidence has a foundationally valid subjective methodology, its false positive rate is substantial and likely to be higher than expected by judicial fact-finders. ${ }^{89}$ It recommended that conclusions need to be accompanied by accurate information about reliability and false positive rates. ${ }^{90}$ Several steps should be taken to further strengthen latent fingerprint analysis, including blind proficiency testing incorporated into regular casework, limiting an

85 Epstein also points out that: " $t$ t]here is considerable disagreement among fingerprint examiners as to how many common ridge characteristics should be found before an identification is made. Examiners historically have employed identification standards ranging from between eight and sixteen matching characteristics, or 'points of similarity.' Many examiners, however, including those at the FBI, currently believe that there should be no minimum standard whatsoever and that the determination of whether there is sufficient basis for identification should be left to the subjective judgement of the individual examiner". For example, England and Wales had 16point fingerprint standards, however, this was abolished in 2000 and identifications are now subject to examiner's judgment. See Epstein date unknown http://wwwbcf.usc.edu/ usclrev/html_articles/075302/075302.htm; Meintjes-van der Walt 2006 SACJ 159; Mnookin 2003 https://issues.org/mnookin/ 1.

For example, Chandler notes that: "the uniqueness of fingerprints cannot be proven since not everyone's fingerprints are recorded and there is no method to compare the fingerprints that are on record". Chandler 2013-2014 Buff Pub Int LJ 50.

See NAS Strengthening Forensic Science 137; Meintjes-van der Walt 2006 SACJ 157-161 and the United States v Bryon Mitchell 2004365 F 3d 215 (3rd Cir) (inconclusive findings to establish the probability of two fingerprints being identical). Meintjes-van der Walt 2006 SACJ 162 and PCAST 2016 https://obamawhitehouse.archives.gov/sites/default/files/microsites/ostp/PCAST/pc ast_forensic_science_report_final.pdf 90. Also see Chiwara Review of Five International Forensic Reports.

PCAST 2016 https://obamawhitehouse.archives.gov/sites/default/files/microsites/ ostp/PCAST/pcast_forensic_science_report_final.pdf 101.

90 PCAST $201 \overline{6} \quad$ https://obamawhitehouse.archives.gov/sites/default/files/ microsites/ostp/PCAST/pcast_forensic_science_report_final.pdf 102-103. 
examiner's access to potentially biasing information and examining and documenting the features of the unknown sample before comparing them to a known sample. ${ }^{91}$ All of these factors should be considered when determining whether the techniques were validly applied in the case at hand.

The lack of a validated scientific standard is a major issue often raised. This is regarding whether the expert witness provided conclusive empirical testing with a determined error rate and whether the expert's findings are credible given that there can be distortion, or smudging or problems regarding the size and clarity of the latent print. ${ }^{92}$ The ACE-V method provides a broad framework for examining the latent prints in order to prove or disprove a similarity ${ }^{93}$ However, it "does not guard against bias; is too broad to ensure repeatability and transparency; and does not guarantee that two analysts following it will obtain the same results". ${ }^{94}$ In addition, the ACE$V$ method does not stipulate specific measurements, standards or statistical models (like in DNA analysis) and much reliance is on the subjective judgement of the examiner. ${ }^{95}$ For these reasons, when an expert uses the ACE-V method, it does not mean the expert is proceeding in a scientific manner or producing reliable results. ${ }^{96}$

These shortcomings have contributed either in part or in total to the wrongful identification and conviction of innocent persons and this is evident in a number of cases. Perhaps the most publicised is the Brandon Mayfield's case, which concerns the misidentification of Mayfield as the source of an unknown print by the Federal Bureau of Investigations (FBI) Laboratory following the investigation into multiple terrorist attacks on commuter trains in Madrid, Spain. ${ }^{97}$ The Spanish National Police, unable to identify the source of an unknown fingerprint on a bag of detonators found at the crime

91 PCAST $2016 \mathrm{https} / / /$ obamawhitehouse.archives.gov/sites/default/files/microsites/ ostp/PCAST/pcast_forensic_science_report_final.pdf 57-58, 102-103. NAS Strengthening Forensic Science 137; Meintjes-van der Walt 2006 SACJ 157; Mnookin 2003 https://issues.org/mnookin/ 1.

$93 \quad$ NAS Strengthening Forensic Science 142.

94 It should be noted that bias often occurs during the final stage of verification where the outcome of first examiner's assessment influences the conclusions of other examiners. However, it is recommended that blind verification be conducted to avoid bias. NAS Strengthening Forensic Science 142 and Chandler 2013-2014 Buff Pub Int LJ 52.

"The statistical models in existence only account for matching points of minutiae and do not take the clarity of the latent print into consideration." See Chandler 2013-2014 Buff Pub Int LJ 51-52; NAS Strengthening Forensic Science 137-141. NAS Strengthening Forensic Science 142.

97 US Department of Justice 2006 https://www.hsdl.org/?abstract\&did=458960 1; Cole 2004-2005 J Crim L \& Criminology 985-986; Chandler 2013-2014 Buff Pub Int LJ 42. 
scene, contacted other police agencies including the $\mathrm{FBI} .{ }^{98}$ The $\mathrm{FBI}$ examiners withdrew their identification of Mayfield after this was discovered it was an error. ${ }^{99}$ Another example is Mckie $v$ Scottish Ministers ${ }^{100}$ which highlight the systemic problems associated with establishing a conclusive fingerprint matching. In this case, despite the use of different highly experienced experts, the outcome of their findings produced widely divergent opinions on the similarities or dissimilarities of the fingerprints obtained at the crime scene and from the suspect. This is largely due to the lack of a scientific basis for analysing the fingerprint evidence.

Furthermore, latent print experts have traditionally used the words "identification" and "individualisation" to show a positive match of an unknown latent print to a specific known source. However, in November 2015, the US Army's Defence Forensic Science Centre (DFSC) gave notice of a change in the use of these terms and directed that experts should refer to the "the concept of likelihood" in their technical reports and expert witness testimony. ${ }^{101}$ The reason for this change is mainly because the words imply "absolute certainty" or "100 percent" or that the method boasts a "zero error rate". ${ }^{102}$ However, neither of these has been conclusively demonstrated through the purported scientific method (latent print). ${ }^{103}$ The DFSC recognised the need to ensure that expert's testimony on forensic science findings is reported in a manner that "appropriately conveys the strength of the evidence...".104 The DFSC'S decision further confirms the uncertainty that exists with the expert's testimony on latent print identification.

US Department of Justice 2006 https://www.hsdl.org/?abstract\&did=458960 1.

US Department of Justice 2006 https://www.hsdl.org/?abstract\&did=458960 1. See also United States v Bryon Mitchell 2004365 F 3d 215 (3rd Cir) where the very foundation of fingerprint identification was challenged in terms of the standards set in Daubert v Merrell Dow Pharmaceuticals, Inc. Also see Cole 2004-2005 J Crim L \& Criminology 985-986. See Mckie $v$ Scottish Ministers 2006 SC 528. Also see Cromwell 2011 https://www.scottishlawreports.org.uk/publications/macfadyen-2011.html\#f71.

101 The change in language clearly reads as follows: "The latent print on Exhibit \#\# and the record finger/palm prints bearing the name XXXX have corresponding ridge detail. The likelihood of observing this amount of correspondence when two impressions are made by different sources is considered extremely low". See Kaye 2015 http://for-sci-law.blogspot.com/2015/11/marching-toward-improved-latent.html and Dawson 2016 Natl Inst Justice $J$ 1-6.

102 Mnookin 2018 https://ssrn.com/abstract=3300354 111.

103 Kaye 2015 http://for-sci-law.blogspot.com/2015/11/marching-toward-improvedlatent.html 1 and Dawson 2016 Natl Inst Justice J 1-6.

104 Kaye 2015 http://for-sci-law.blogspot.com/2015/11/marching-toward-improvedlatent.html 1 and Dawson 2016 Natl Inst Justice J 1-6. 
Kadane states that:

... the finding of similarities between the mark found at a crime scene and a fingerprint on file does not permit estimation of the number of persons in a given population who share those characteristics. Consequently, there is no scientific basis for a source attribution; whether phrased as a 'match' as 'individualization' or otherwise. ${ }^{105}$

He sees it as circumstantial evidence and not direct evidence ${ }^{106}$ and as such it allows for more than one explanation.

\subsection{Bite mark analysis}

Bite marks are patterned marks (injury) made by human teeth on the skin of a victim of a crime or on an object at a crime scene. ${ }^{107}$ Bite mark analysis is an important area of forensic odontology which is the application of the science of dentistry to law. ${ }^{108}$ This article does not attempt to discuss the broad scope of forensic odontology but focuses on bite mark analysis which involves examining and comparing the marks made on the skin of the victim or an object and the dental impressions obtained from an accused person. ${ }^{109}$ The expert known as forensic odontologist collects bite mark evidence during investigations of crimes, such as homicide, sexual assault and child abuse. ${ }^{110}$ The methods of collection of evidence which are generally recognised as "relatively noncontroversial" include "various forms of photography, dental casts, clear overlays, computer enhancement, electron microscopy, and swabbing for serology...". 111

\footnotetext{
105 Kadane date unknown https://pdfs.semanticscholar.org/7925/ 4e4ec0ecc46ab24e14da0788dab8028107b1.pdf.

106 Kadane date unknown https://pdfs.semanticscholar.org/7925/ 4e4ec0ecc46ab24e14da0788dab8028107b1.pdf and Rea 2017 https://www.cmu.edu/dietrich/news/news-stories/2017/february/fingerprintscience.html.

107 NAS Strengthening Forensic Science 173; PCAST 2016 https://obamawhitehouse.archives.gov/sites/default/files/microsites/ostp/PCAST/pc ast_forensic_science_report_final.pdf 8, 83; Saks et al 2016 JLB 538-575.

108 NAS Strengthening Forensic Science 173.

109 PCAST 2016 https://obamawhitehouse.archives.gov/sites/default/files/ microsites/ostp/PCAST/pcast_forensic_science_report_final.pdf 8, 83.

110 NAS Strengthening Forensic Science 173-174.

111 NAS Strengthening Forensic Science 173-174.
} 
Bite mark analysis is based on the premise that:

(1) dental characteristics, particularly the arrangement of the front teeth, differ substantially among people and (2) skin (or some other marked surface at a crime scene) can reliably capture these distinctive features. ${ }^{112}$

This implies that each person's dentition is unique and that the human skin can reliably record a person's bite marks. On the basis of this assumption, many courts have accepted the admissibility of an expert's testimony for the purpose of identification. ${ }^{113}$ However, several reports have cast serious doubt on the accuracy of these premises. ${ }^{114}$ For example, the NAS Report notes that the "uniqueness of the human dentition" and the ability "to transfer a unique pattern to human skin and the ability of the skin to maintain that uniqueness has not been scientifically established". ${ }^{115}$ Also, the "ability to analyse and interpret the scope or extent of distortion of bite mark on human skin is yet to be demonstrated". ${ }^{116}$

The PCAST Report, a more recent study, also states that "bite mark analysis does not meet the scientific standards for foundational validity" and the current standards to determine a degree of similarity is not well defined. ${ }^{117}$ The conclusions drawn from the bite marks comparison method is based mainly on human (subjective) judgement which may result in a high probability of error, inconsistency and cognitive bias. ${ }^{118}$ In State $v$ Krone ${ }^{119}$ the accused was convicted by two juries for murder based on bite marks

112 PCAST $2016 \quad$ https://obamawhitehouse.archives.gov/sites/default/ files/microsites/ostp/PCAST/pcast_forensic_science_report_final.pdf 8, 83.

113 See, for example, in Brooks $v$ State 748 So $2 d 736$ (Miss 1999) the court held that bite mark testimony is admissible in Mississippi without much focus on the scientific basis of the evidence; Carter $v$ State 766 NE 2d 377 (Ind 2002) 380 where the court accepted a bite mark testimony because there was no reason why the evidence should be considered as unreliable. Also see Beecher-Monas Evaluating Scientific Evidence 96 fn 7; Saks et al 2016 JLB 542 fn 8.

114 See, for example, NAS Strengthening Forensic Science 175 and PCAST 2016 https://obamawhitehouse.archives.gov/sites/default/files/microsites/ostp/PCAST/pc ast_forensic_science_report_final.pdf 87.

115 See NAS Strengthening Forensic Science 175.

116 See NAS Strengthening Forensic Science 175-176.

117 PCAST $2016 \mathrm{https} / / /$ obamawhitehouse.archives.gov/sites/default/files/microsites/ ostp/PCAST/pcast_forensic_science_report_final.pdf 8-9, 87.

118 PCAST $2016 \mathrm{https}: / /$ obamawhitehouse.archives.gov/sites/default/files/microsites/ ostp/PCAST/pcast_forensic_science_report_final.pdf 5, 83. See also People $v$ Brown 618 NYS 2d 188, 188 (NY Co Ct 1994), aff'd, 600 NYS 2d 593 (NY App Div 4th Dept 1993) cited in Cooley and Oberfield 2013 Tulsa L Rev 297 fn 99. In this case, Brown was convicted of murder based on bite mark comparison with obvious discrepancies between Brown's teeth and the bite mark, concluded that Brown could have left the bite mark. However, a DNA testing exonerated Brown.

119 State v Krone 897 P 2d 621 (Ariz 1995). Also see Cooley and Oberfield 2013 Tulsa L Rev 295-296 
evidence. The Styrofoam (casts) impression of Krone's dentition compared with the bite marks on the victim's body, suggested a pattern match. ${ }^{120}$ However, Krone's conviction was overturned after DNA testing of saliva found on the victim's top excluded Krone from the murder. ${ }^{121}$

The problems associated with bite mark analysis affect the validity and reliability of the method. Therefore, as concluded in both NAS and PCAST Reports, much more research is needed to establish the scientific validity of this method so that expert testimony can be readily accepted in court and that wrongful convictions can be avoided. ${ }^{122}$

\subsection{Microscopic hair analysis}

Space restrictions do not allow for a detailed discussion of microscopic hair analysis (or comparison) which involves examining and comparing features of hair found at the crime scene and hair taken from an accused to establish whether or not the accused is the source of the questioned hair. ${ }^{123}$ The basis for this method stems "from the fact that human and animal hairs routinely are shed and thus are capable of being transferred from an individual to the crime scene, and from the crime scene to an individual". ${ }^{124}$ Therefore, in an attempt to find out whether or not the suspect is the source of the questioned hair obtained from the crime scene, an examiner's first step is to determine the following: ${ }^{125}$

(1) whether the hair is of human or animal origin, (2) the part of the body that the hair came from (scalp, pubic, or limb hair), (3) racial origin, (4) whether the hair has been dyed, (5) whether the hair was pulled or fell out as a result of natural causes or disease, and (6) whether the hair was cut or crushed.

The next step is to examine the hair macroscopically to identify certain features like hair colour (eg black, brown or grey) or hair structure (eg straight, wavy, and curved). ${ }^{126}$ The third step is to examine the hair

$120 \quad$ State $v$ Krone 897 P 2d 621 (Ariz 1995).

121 See Cooley and Oberfield 2013 Tulsa $L$ Rev 295-300. Also see Burke $v$ Town of Walpole $405 \mathrm{~F}$ 3d 66 (1st Cir 2005). In this case, bite mark analysis led to the wrongful arrest for 41 days for murder. However, DNA testing of the suspect's saliva excluded him.

PCAST 2016 https://obamawhitehouse.archives.gov/sites/default/files/microsites/ ostp/PCAST/pcast_forensic_science_report_final.pdf 87 and NAS Strengthening Forensic Science 175-176.

123 PCAST $2016 \mathrm{https}: / /$ obamawhitehouse.archives.gov/sites/default/files/microsites/ ostp/PCAST/pcast_forensic_science_report_final.pdf 13; Sangero 2018 Ga St UL Rev 1203.

124 NAS Strengthening Forensic Science 155-156.

125 Giannelli 2010 Case Research Paper Series in Legal Studies 2; NAS Strengthening Forensic Science 156-157. 
microscopically to determine more features of the hair (eg, pigment size or shaft diameter). ${ }^{127}$ Sangero points out that the characteristics to be determined in this process are not "consistent for even one individual's hair" due to variations. ${ }^{128}$ Therefore "this type of comparison between pieces of hair from two different people often points to an alleged match". ${ }^{129}$

There is an assumption that microscopic hair analysis "can yield reliable information about class characteristics of hair strands" which can help to narrow down a possible source of unknown hair. ${ }^{130}$ Based on this assumption, microscopic hair analysis has been admitted by many courts and in State $v$ West the court explicitly stated that "microscopic comparison of morphological characteristics of human hairs has been accepted both scientifically and legally for decades". ${ }^{131}$

However, microscopic hair comparison has been recognised as "highly unreliable"132 as "no scientifically accepted statistics exist about the frequency with which particular characteristics of hair are distributed in the population". ${ }^{133}$ Furthermore, there are "no uniform standards on the number of features on which hairs must agree before an examiner may declare a 'match'". ${ }^{134}$ The conclusions drawn from hair comparison is mainly based on human judgement. ${ }^{135}$

Flaws identified with this method are linked to several cases of wrongful convictions. ${ }^{136}$ In Williamson $v$ State, the court held that the microscopic hair analysis presented in court was "irrelevant, imprecise and speculative and its probative value was outweighed by its prejudicial effect". ${ }^{137}$

The extent of the unreliability of microscopic hair comparison is pointed out by Sangero: ${ }^{138}$

\footnotetext{
127 NAS Strengthening Forensic Science 156-157; Giannelli 2010 Case Research Paper Series in Legal Studies 2.

128 Sangero 2018 Ga St UL Rev 1203.

129 Sangero 2018 Ga St UL Rev 1203.

130 Giannelli 2010 Case Research Paper Series in Legal Studies 3.

131 State $v$ West 877 A 2d 787 (Conn 2005). Also see NAS Strengthening Forensic Science 161.

132 NAS Strengthening Forensic Science 161; Giannelli 2010 Case Research Paper Series in Legal Studies 1.

NAS Strengthening Forensic Science 160.

NAS Strengthening Forensic Science 160.

Giannelli 2010 Case Research Paper Series in Legal Studies 3-4.

Sangero 2018 Ga St UL Rev 1201-1205.

Williamson v State 812 P 2d 384 (Okla Crim App 1991). Also see Cooley and Oberfield 2013 Tulsa L Rev 301-303.

138 Sangero 2018 Ga St UL Rev 1202.
} 
In twenty-one of the first seventy exonerations in which the Innocence Project was involved, experts gave erroneous testimony on the microscopical comparison of hair. In a later study, it emerged that in seventy-five of the Project's first 250 exonerations, the convictions had also been based on microscopical comparisons of hair, and in twenty-nine of these cases experts gave erroneous testimony. In eighteen of the cases, moreover, the experts had grounded their testimony on an individualization claim; that is to say, that the hair found at the scene of the crime was unique to the defendant. In six of the exoneration cases, mitochondrial DNA testing ruled out the expert's assessment of a match between the hair at the scene of the crime and the defendant's hair.

Mnookin notes that the recent reports from the FBI and the Innocence Project found that "...microscopic hair identification experts regularly overstated their conclusions when testifying, frequently going well beyond what the field ostensibly permitted". ${ }^{139}$ The flaws in this method cast serious doubt on the validity and reliability of microscopic hair analysis.

\subsection{Firearm identification}

In firearms identification, examiners generally "attempt to determine whether ammunition is or is not associated with a specific firearm based on 'tool marks' produced by guns on the ammunition". ${ }^{140}$ Examiners establish that a specific firearm is the source (or not) of a particular bullet, cartridge case, shotshell casing or slug etc found at the crime scene. ${ }^{141}$

The basis of firearms identification is the principle of uniqueness, in which each tool mark produced by different firearms are presumed to be unique and is considered to vary substantially from one another. ${ }^{142}$ This is because each tool mark has individual characteristics (resulting from variations in manufacture and use) that may be uniquely associated with a specific tool or firearm and are reproduced by the same specific tool or firearm. ${ }^{143}$ According to the PCAST Report, firearm examination "begins with an

139 See reports: Hsu 2015 https://www.washingtonpost.com/local/crime/fbi-overstatedforensic-hair-matches-in-nearly-all-criminal-trials-fordecades/2015/04/18/39c8d8c6-e515-11e4-b510-

962fcfabc310_story.html?noredirect=on\&utm_term=.c22d03885a0e; FBI 2015 https://www.fbi.gov/news/pressrel/press-releases/fbi-testimony-on-microscopichair-analysis-contained-errors-in-at-least-90-percent-of-cases-in-ongoing-review; Mnookin 2018 https://ssrn.com/abstract=3300354 103 fn 7.

140 PCAST $2016 \mathrm{https}: / /$ obamawhitehouse.archives.gov/sites/default/files/microsites/ ostp/PCAST/pcast_forensic_science_report_final.pdf 11.

141 PCAST 2016 https://obamawhitehouse.archives.gov/sites/default/files/microsites/ ostp/PCAST/pcast_forensic_science_report_final.pdf 11. See also the National Forensic Science - Technology Center date unknown http://www.forensicsciencesimplified.org/prints/Fingerprints.pdf 1.

142 NAS Strengthening Forensic Science 150.

143 NAS Strengthening Forensic Science 150. 
evaluation of class characteristics of the bullets and casings, which are features that are permanent and predetermined before manufacture". ${ }^{144}$ In a case where the:

... class characteristics are different, an elimination conclusion is rendered. If the class characteristics are similar, the examination proceeds to identify and compare individual characteristics, such as the markings that arise during firing from a particular gun. ${ }^{145}$

According to the PCAST Report, the "most widely accepted method used in conducting a toolmark examination is a side-by-side, microscopic comparison of the markings on a questioned material item to known source marks imparted by the tool". ${ }^{146}$ The conclusions drawn from the examination is based on the subjective judgments of the examiner and the accuracy of the assessments is highly dependent on the examiner's acquired skill and training. ${ }^{147}$

While this method of identification is commonly used in criminal cases and accepted by the courts, some fundamental problems have been identified. The assumption of the uniqueness of tool marks has been criticised by both the NAS and the PCAST Reports which note that "the validity of the fundamental assumptions of uniqueness and reproducibility of firearmsrelated tool marks has not yet been fully demonstrated". ${ }^{148}$ The NAS Report further asserts that in making a comparison between firearms-related tool marks, there is the possibility of similarity on bullets and cartridge cases from the same gun, but there is the need for caution and for scientific-based research that can determine the degree to which firearm-related tool marks are unique. ${ }^{149}$

It should be noted that some courts have ruled on the admissibility of an expert's testimony based on the argument that a bullet or cartridge case is produced from the same gun. For example, in United States $v$ Monteirio ${ }^{150}$

144 PCAST $2016 \mathrm{https}: / /$ obamawhitehouse.archives.gov/sites/default/files/microsites/ ostp/PCAST/pcast_forensic_science_report_final.pdf 11; Kaplan and Puracal 2018 Alb L Rev 2018 904-905.

145 National Forensic Science Technology Center date unknown http://www.forensicsciencesimplified.org/prints/Fingerprints.pdf 1; Kaplan and Puracal 2018 Alb L Rev 904-905.

146 PCAST $2016 \mathrm{https}: / /$ obamawhitehouse.archives.gov/sites/default/files/microsites/ ostp/PCAST/pcast_forensic_science_report_final.pdf 104.

147 NAS Strengthening Forensic Science 153.

148 See NAS Strengthening Forensic Science 154 and PCAST 2016 https://obamawhitehouse.archives.gov/sites/default/files/microsites/ostp/PCAST/pc ast_forensic_science_report_final.pdf 105.

149 NAS Strengthening Forensic Science 154.

150 United States v Monteiro 407 F Supp 2d 351 (D Mass 2006). 
the motion brought before the court by the accused, was for the court to exclude expert testimony that cartridge cases found at several crime scenes matched the firearms linked to the defendant. The expert testimony was based on the assumption of the uniqueness of toolmarks and the accused wanted the court to declare the method unreliable under the standards set in the Daubert case. However, the court held that "the underlying scientific principle behind firearm identification that firearms transfer unique toolmarks to spent cartridge cases, is valid under Daubert'. ${ }^{151}$

Nevertheless, Judge Saris, in the Monteiro case, stated that: ${ }^{152}$

Because an examiner's bottom line opinion as to identification is largely a subjective one, there is no reliable statistical or scientific methodology which will currently permit the expert to testify that it is a 'match' to an absolute certainty, or to an arbitrary degree of statistical certainty. ${ }^{153}$

The Supreme Court in Ramirez $v$ State of Florida ${ }^{154}$ cautioned firearm and toolmark examiners regarding relying on:

"... nothing more than their own subjective criteria for 'striae identification' and those who are unable to put forth "a convincing, logical, scientifically based explanation for the basis of their identifications"." 155

In United States $v$ Green ${ }^{156}$ the expert testified that a match could be made between two casings and that the casings came from a specific firearm "to the exclusion of every other firearms in the world". The testimony lacked empirical testing and the court allowed the expert only to explain the ways in which the casings were similar but not that they came from a specific weapon "to the exclusion of every other firearms in the world". ${ }^{157}$ The court cautioned that: ${ }^{158}$

United States v Monteiro 407 F Supp 2d 351 (D Mass 2006).

United States v Monteiro 407 F Supp 2d 351 (D Mass 2006) 372.

Emphasis added. Instead of articulating criteria, most examiners rely solely on subjective, mind's eye judgments of when the resemblances between tool marks are sufficient to justify identity conclusions. See Schwartz 2008 https://www.wispd.org/images/practicegroups/homicide/ChallengingFirearmsIdentificationpart2.pdf 49-50.

Ramirez v State of Florida SC92975 (20 December 2001).

Grzybowski et al 2003 AFTE Journal 2.

United States v Green 405 F Supp 2d 104 (D Mass 2005). See also Giannelli 2010 Faculty Publications 1143-1144.

United States v Green 405 F Supp 2d 104 (D Mass 2005). See also Giannelli 2010 Faculty Publications 1143-1144.

United States v Green 405 F Supp 2d 104 (D Mass 2005). See also Giannelli 2010 Faculty Publications 1143-1144. 
The more courts admit this type of tool mark evidence without requiring documentation, proficiency testing, or evidence of reliability, the more sloppy practices will endure; we should require more.

Furthermore, the subjective judgements of the examiners have been criticised as problematic because it lacks scientific and statistical proof to corroborate an examiner's conclusions. ${ }^{159}$ According to the PCAST Report, neither an examiner's skill, experience nor judgement can be used to establish the scientific validity or reliability of firearms identification. ${ }^{160}$ The report further notes that: ${ }^{161}$

The frequency with which a particular pattern or set of features will be observed in different samples, which is an essential element in drawing conclusions, is not a matter of 'judgment.' It is an empirical matter for which only empirical evidence is relevant.

The lack of an objective standards for examining firearms is a major flaw that raises fundamental questions on the reliability of firearms identification and the possibility of human error in judgment. Therefore, as recommended in the PCAST Report, there is the need for the development of objective methods similar to those used in DNA analysis. ${ }^{162}$

\section{Dangers of convictions based on a single piece of forensic evidence and some recommendations on the way forward}

The wrongful conviction of an innocent person, especially on a single piece of evidence, poses serious risks for the victim and the society at large. ${ }^{163}$ Wrongful conviction is a clear miscarriage of justice that affects the fundamental rights of the convicted person. Such rights include the right to life, the right to liberty and security, as well as the right to human dignity. ${ }^{164}$

159 PCAST 2016 https://obamawhitehouse.archives.gov/sites/default/files/microsites/ ostp/PCAST/pcast_forensic_science_report_final.pdf 55-60; NAS Strengthening Forensic Science 153-154.

160 PCAST $2016 \mathrm{https}: / /$ obamawhitehouse.archives.gov/sites/default/files/microsites/ ostp/PCAST/pcast_forensic_science_report_final.pdf 55 .

161 PCAST $2016 \mathrm{https}: / /$ obamawhitehouse.archives.gov/sites/default/files/microsites/ ostp/PCAST/pcast_forensic_science_report_final.pdf 55 .

162 PCAST $2016 \mathrm{https}: / /$ obamawhitehouse.archives.gov/sites/default/files/microsites/ ostp/PCAST/pcast_forensic_science_report_final.pdf 125, 129.

163 Sangero and Halpert 2007 Jurimetrics $J 46$.

164 These rights are well established in international and regional human rights instruments. See, for example, the Universal Declaration of Human Rights (1948) (art 3: Everyone has the right to life, liberty and security of person); the International Covenant on Civil and Political Rights (1966) (ICCPR) (art 9(1): Everyone has the right to liberty and security of person); African Charter on Human and Peoples Rights (1981) (ACHPR) (art 4: right to life, art 5: prohibition of torture and cruel, inhuman 
Furthermore, convicted persons are faced with the challenges (i.e. delay regarding court processes) and the cost of appealing their conviction as well as the cost of pursuing legal remedies from the court as compensation for wrongful conviction, when exonerated and released.

The danger for society is that the real perpetrator of the crime remains within the society and there is a high possibility of a reoccurrence of the crime. ${ }^{165}$ Also, the state is faced with the high cost of complying with the order of the court regarding legal remedies for the convicted person.

As explained above, serious flaws are associated with forensic patternmatching methods and are linked to the wrongful conviction of an innocent person based on a single piece of forensic evidence. Despite the flaws, some courts still admit forensic expert testimony based on pattern-matching methods as scientific evidence. ${ }^{166}$ This is confirmed by Mnookin: ${ }^{167}$

\begin{abstract}
Judges today are tremendously reluctant to exclude from trials long familiar forms of forensic science evidence even when... the scientific foundation is weak and the evidence has played an established role in numerous proven wrongful convictions.
\end{abstract}

However, detailed recommendations addressing the flaws in order to ensure a more scientifically valid and reliable foundation for forensic evidence, are provided in both the NAS and PCAST reports, some of which are highlighted above. The findings and recommendations in these detailed reports as well as in other scholarly articles in the field of the forensic disciplines and criminal law, provide a strong foundation for continuous education, training and awareness regarding pattern-matching methods. ${ }^{168}$ Mnookin rightly observes that since the release of the NAS Report, and the subsequent PCAST Report, there has been a change in the conversation on pattern-matching methods. ${ }^{169}$ However, there is a need for an increased conscious effort with regard to educating and training relevant stakeholders, such as judges, prosecutors, defence attorneys, forensic experts and examiners etc. ${ }^{170}$ Furthermore, there is a need to raise awareness in order

and degrading treatment, art 6 : right to liberty and security of person). These rights are also enshrined in the South African Bill of Rights, specifically, ss 10-12 of the Constitution of the Republic of South Africa, 1996.

165 Sangero and Halpert 2007 Jurimetrics J 46.

166 Sangero $2018 \mathrm{Ga}$ St UL Rev 1130.

167 Mnookin $2018 \mathrm{https}: / /$ ssrn.com/abstract=3300354 102-105.

168 See, for example, Sangero 2018 Ga St UL Rev 1129-1220; Sangero and Halpert 2007 Jurimetrics J 43-94; Mnookin 2018 https://ssrn.com/abstract=3300354 102105.

169 Mnookin 2018 https://ssrn.com/abstract=3300354 110.

170 Mnookin 2018 https://ssrn.com/abstract=3300354 105. 
to generate more focus and more research both at national and international levels on the scope of pattern-matching methods; the gaps in knowledge regarding the validity and reliability of the methods; establishing error rates and ensuring the accuracy of examiners findings. ${ }^{171}$ These suggestions are important because at present attempts at effective implementation of the recommendations in the reports are slow and greater progress is needed. ${ }^{172}$

While an effort is being made to implement these recommendations and create awareness, this article contends that courts should follow a cautionary approach when relying on forensic evidence which is scientifically unvalidated and that strong corroboration with other forms of evidence linking the accused to the crime, should be required. ${ }^{173}$ The need for caution, especially in the South African courts, is important for the following reasons: Firstly, forensic pattern-matching methods are not errorfree and there is the reality of high occurrence of wrongful conviction of innocent persons. ${ }^{174}$ Secondly, reliability is not a prerequisite for the admissibility of forensic evidence in South Africa. ${ }^{175}$ As explained above, the Daubert case requires high standards for considering when to admit expert testimony. Thirdly, there is a need to prevent the misuse of the legal principle which provides that an accused can be convicted on any offence based on the evidence of any single competent witness. ${ }^{176}$ Fourthly, the need for caution is also prompted by the state's failure, at times, to adduce real evidence which should have been available. ${ }^{177}$ Therefore, the court must encourage the state to provide additional material evidence, if available, to corroborate the circumstantial evidence (ie forensic evidence) in order to reinforce their argument(s).

Sangero asserts that "the aura of science can be expected [or has a possibility] to blind judges and jurors and lead them to overestimate the real

\footnotetext{
171 Mnookin 2018 https://ssrn.com/abstract=3300354 102-105.

172 Mnookin $2018 \mathrm{https}: / /$ ssrn.com/abstract=3300354 100-102 and PCAST 2016 https://obamawhitehouse.archives.gov/sites/default/files/microsites/ostp/PCAST/pc ast_forensic_science_report_final.pdf 9 .

173 See S v Msane 19774 SA $7 \overline{5} 8(\mathrm{~N})$.

174 Sangero 2018 Ga St UL Rev 1129-1132

175 But recently there seems to be a tendency to require expert evidence to be not only relevant but also reliable. This is pointed out in Twine $v$ Naidoo 20181 All SA 297 (GJ), where Vally $\mathrm{J}$ notes that the learning over the years has established principles regarding expert witnesses including that "...expert testimony should only be introduced if it is relevant and reliable. Otherwise it is inadmissible". Also see $A R v$ Road Accident Fund 2018 ZAGPJHC 637 (29 November 2018) para 37 and Edmond and Meintjes-van der Walt 2014 SALJ 113.

176 See s 208 of the South African Criminal Procedure Act 51 of 1977.

177 See S v Msane 19774 SA $758(\mathrm{~N})$.
} 
probative strength of scientific evidence". ${ }^{178}$ Although science is generally held in high esteem, ${ }^{179}$ the court in Holtzhauzen $v$ Roodt notes that: ${ }^{180}$

The expertise of the witness should not be elevated to such an extent that the court loses sight of its own capabilities and responsibilities in drawing inferences from the evidence.

However, the reality is that judges often have to rely heavily on the specialised knowledge and skill of expert witnesses in order to draw inferences and to reach conclusions, while the expert's testimony, purported to be based on science, may be erroneous. ${ }^{181}$ Brandon Mayfield's case is a popular example of this argument that well-qualified experts with years of experience and knowledge can and do make mistakes in findings and judgement.

Lastly, the high crime rate and violence in South Africa could support an assumption (often public opinion judgement which can dissuade an expert to make an inconclusive finding / judgement) that a suspect is guilty of a crime (even before proving his or her guilt beyond reasonable doubt in court). ${ }^{182}$ The high crime rate contributes to why wrongful convictions remain "mostly unacknowledged, usually ignored and often denied" in South Africa. ${ }^{183}$

\section{Conclusion}

The article above examines the dangers of conviction based on a single piece of forensic evidence. There can be no doubt that forensic evidence contributes immensely to criminal investigations and prosecutions. Traditionally, expert testimony, especially on pattern-matching methods (fingerprint analysis, bite mark identification, microscopic hair analysis and firearms identification) has been generally accepted in South African courts but, in the light of the above, for any forensic evidence meaningfully to contribute to the successful outcome of a trial, it must be accurate, relevant,

\footnotetext{
178 Sangero 2018 Ga St UL Rev 1135.

179 This is because it is believed to entail objective methods which will ensure greater accuracy, lower risks of human error or cognitive bias and establish foundational validity and reliability. Sangero 2018 Ga St UL Rev 1136-137. Holtzhauzen v Roodt 19974 SA 766 (W) 772E-G. Also see Edmond and Meintjesvan der Walt 2014 SALJ 112.

181 Sangero $2018 \mathrm{Ga}$ St UL Rev 1136-137; Cromwell 2011 https://www.scottishlawreports.org.uk/publications/macfadyen-2011.html\#f71.

182 Raphaely 2018 https://www.dailymaverick.co.za/article/2018-10-02-getting-itwrong-guilty-until-proven-innocent/ (the recent acquittal of a South African man wrongfully convicted of rape at the Pietermaritzburg High Court).

183 Raphaely 2018 https://www.dailymaverick.co.za/article/2018-10-02-getting-itwrong-guilty-until-proven-innocent/.
} 
scientifically valid and reliable. The lack of scientific validity is the main problem affecting pattern-matching methods. Different proposals and recommendations for reforms that will ensure a more scientific method, have been proffered in detailed reports and studies, some of which are mentioned above. However, at present, implementation is slow and therefore there is the need for the courts to exercise caution especially when the conviction is based on a single piece of forensic evidence.

\section{Bibliography}

\section{Literature}

Beecher-Monas Evaluating Scientific Evidence

Beecher-Monas E Evaluating Scientific Evidence: An Interdisciplinary Framework for Intellectual Due Process (Cambridge University Press New York 2007)

Bernstein 1996 Yale J Int'l L

Bernstein D 1996 "Junk Science in the United States and the Commonwealth" 1996 Yale J Int'l L 124-182

Champod and Chamberlain "Fingerprints"

Champod $\mathrm{C}$ and Chamberlain $\mathrm{P}$ "Fingerprints" in Fraser $\mathrm{J}$ and Williams $\mathrm{R}$ (eds) Handbook of Forensic Science (Willan Cullompton 2009) 57-83

Chandler 2013-2014 Buff Pub Int LJ

Chandler D "The Reliability and Admissibility of Fingerprint and Bitemark Analyses" 2013-2014 Buff Pub Int LJ 41-62

Chiwara Review of Five International Forensic Reports

Chiwara MD A Review of Five International Forensic Reports: Fingerprint Evidence Lessons for South African Lawyers (LLM-dissertation University of Fort Hare 2018)

Cole 2004-2005 J Crim L \& Criminology

Cole $S$ "More than Zero: Accounting for Error in Latent Fingerprint Identification" 2004-2005 J Crim L \& Criminology 985-1078

Cole 2006 Golden Gate UL Rev

Cole S "The Prevalence and Potential Causes of Wrongful Conviction" 2006 Golden Gate UL Rev 39-105

Cooley and Oberfield 2013 Tulsa L Rev 
Cooley MC and Oberfield SG "Increasing Forensic Evidence's Reliability and Minimising Wrongful Convictions: Applying Daubert isn't the Only Problem" 2013 Tulsa L Rev 285-380

Dawson 2016 Natl Inst Justice J

Dawson J "Forensic Science: A Time of Transformation" 2016 Natl Inst Justice J 1-6

Edmond and Meintjes-van der Walt 2014 SALJ

Edmond $G$ and Meintjes-van der Walt $L$ "Blind Justice? Forensic Science and the Use of Closed-circuit Television Images as Identification Evidence in South Africa" 2014 SALJ 109-148

Garrett and Neufeld 2009 Va $L$ Rev

Garrett B and Neufeld P "Invalid Forensic Science Testimony and Wrongful Convictions" 2009 Va L Rev 1-97

Giannelli 1980 Colum L Rev

Giannelli PC "The Admissibility of Novel Scientific Evidence: Frye $v$ the United States, a Half-Century Later" 1980 Colum L Rev 1197-1250

Giannelli 2010 Case Research Paper Series in Legal Studies Giannelli PC "Microscopic Hair Comparisons: A Cautionary Tale - Working Paper 2010-17" 2010 Case Research Paper Series in Legal Studies 1-24

Giannelli 2010 Faculty Publications Giannelli PC "Scientific Evidence in Criminal Prosecutions: A Retrospective" 2010 Faculty Publications 1143-1144

Griffin 2001 Am U Int'l L Rev

Griffin L "The Correction of Wrongful Convictions: A Comparative Perspective" 2001 Am U Int'l L Rev 1241-1308

Grzybowski et al 2003 AFTE Journal

Grzybowski R et al "Firearm/Toolmark Identification: Passing the Reliability Test inder Federal and State Evidentiary Standards" 2003 AFTE Journal 134

Hornby Oxford Advanced Learner's Dictionary

Hornby AS Oxford Advanced Learner's Dictionary $9^{\text {th }}$ ed (Oxford University Press Oxford 2015)

Kaplan and Puracal 2018 Alb L Rev 
Kaplan A and Puracal J "It's not a Match: Why the Law can't Let Go of Junk Science" 2018 Alb L Rev 895-939

Kaye 2010 Brook L Rev

Kaye DH "Probability, Individualization, and Uniqueness in Forensic Science Evidence: Listening to the Academies" 2010 Brook L Rev 11631185

Koehler 2008 Hastings LJ

Koehler JJ "Fingerprint Error Rates and Proficiency Tests: What they are and Why they Matter" 2008 Hastings Law Journal 1077-1098

Langbein Origin of Adversary Criminal Trial

Langbein HJ The Origin of Adversary Criminal Trial (Oxford University Press Oxford 2003)

Meintjes-van der Walt 2006 SACJ

Meintjes-van der Walt L "Fingerprint Evidence: Probing Myth and Reality" 2006 SACJ $152-172$

NAS Strengthening Forensic Science

Committee on Identifying the Needs of the Forensic Sciences Community, Research Council of the National Academy of Sciences Strengthening Forensic Science in the United States: A Path Forward (National Research Press Washington DC 2009)

Newton DNA Evidence and Forensic Science

Newton D DNA Evidence and Forensic Science (Infobase New York 2008)

Saks et al $2016 \mathrm{JLB}$

Saks MJ et al "Forensic Bitemark Identification: Weak Foundations, Exaggerated Claims" 2016 JLB 538-575

Saks and Koehler 2008 Vand L Rev

Saks MJ and Koehler JJ "The Individualisation Fallacy in Forensic Science Evidence" 2008 Vand L Rev 199-219

Sangero 2018 Ga St UL Rev

Sangero B "Safety from Flawed Forensic Sciences Evidence" 2018 Ga St UL Rev 1129-1220

Sangero and Halpert 2007 Jurimetrics $J$

Sangero B and Halpert M "Why a Conviction should not be Based on a Single Piece of Evidence: A Proposal for Reform" 2007 Jurimetrics J 43-94 
Schwikkard and Van der Merwe Principles of Evidence

Schwikkard PJ and Van der Merwe SE Principles of Evidence $4^{\text {th }}$ ed (Juta Cape Town 2016)

Zeffertt and Paizes South African Law of Evidence

Zeffertt DT and Paizes AP The South African Law of Evidence $3^{\text {rd }}$ ed (Lexis Nexis Butterworths 2009)

Case law

AR v Road Accident Fund 2018 ZAGPJHC 637 (29 November 2018)

B v S 2016 ZAFSHC 100 (12 May 2016)

Brooks v State 748 So 2d 736 (Miss 1999)

Burke v Town of Walpole 405 F 3d 66 ( $1^{\text {st }}$ Cir 2005)

Carter v State 766 NE 2d 377 (Ind 2002)

Cele v S 2010 ZAKZPHC 26 (25 May 2010)

Commonwealth v Cowans 756 NE 2D 622 (Mass App Ct 2001)

Daubert v Merrell Dow Pharmaceuticals, Inc 1993509 US 579

Frye v United States 293 F 1013 (DC Cir 1923)

Green v R 1971126 CLR 28

Holtzhauzen v Roodt 19974 SA 766 (W)

Kumho Tire Co v Carmichael 1999526 US 137

Mckie v Scottish Ministers 2006 SC 528

Nduna v S 2010 ZASCA 120 (30 September 2010)

Nkuna v S 2018 ZALMPPHC 21 (11 May 2018)

People v Brown 618 NYS 2d 188, 188 (NY Co Ct 1994), aff'd, 600 NYS 2d 593 (NY App Div 4th Dept 1993)

Ramirez v State of Florida SC92975 (20 December 2001)

Regina v Adams 19962 Cr App R 467 
$R v W 19493$ SA 773 (AD)

$S$ v Artman 19683 SA 339 (A)

S v Baloyi 20002 SA 425 (CC)

S v Ganie 19674 SA 203 (N)

S v Gokool 19653 SA 461 (N)

S v Gumede1982 4 SA 561 (T)

S v Mbatha 2018 ZAGPJHC 502 (13 August 2018)

S v Msane 19774 SA $758(\mathrm{~N})$

$S$ v Nala 19654 SA $360(\mathrm{~A})$

$S$ v Nyathe 19882 SA $211(0)$

$S$ v Sauls 19813 SA $172(\mathrm{~A})$

$S v$ Stevens 20051 All SA 1 (SCA)

State v Krone 897 P 2d 621 (Ariz 1995)

State $v$ West 877 A 2d 787 (Conn 2005)

Twine v Naidoo 20181 All SA 297 (GJ)

The Queen v Dookheea 2017 HCA 36; 91 ALJR 960

United States v Bryon Mitchell 2004365 F 3d 215 (3rd Cir)

United States v Green 405 F Supp 2d 104 (D Mass 2005)

United States v Monteiro 407 F Supp 2d 351 (D Mass 2006)

United States v Scheffer 1998523 US 303

United States v William 1978583 F 2d 1194

Williamson v State 812 P 2d 384 (Okla Crim App 1991)

\section{Legislation}

\section{South Africa}


Constitution of the Republic of South Africa, 1996

Criminal Procedure Act 51 of 1977

\section{United States}

Federal Rules of Evidence, 1975 (as amended)

International instruments

African Charter on Human and Peoples Rights (1981)

International Covenant on Civil and Political Rights (1966)

Universal Declaration of Human Rights (1948)

\section{Internet sources}

Bell et al 2018 http://www.pnas.org/content/pnas/115/18/4541.full.pdf Bell S et al 2018 A Call for More Science in Forensic Science - Proceedings of the National Academy of Sciences http://www.pnas.org/ content/pnas/115/18/4541.full.pdf accessed 31 October 2018

Budowle, Buscaglia and Swartz Perlman 2006 https://archives.fbi.gov/archives/about-us/lab/forensic-sciencecommunications/fsc/jan2006/research/2006_01_research02.htm Budowle B, Buscaglia J and Swartz Perlman R 2006 Review of the Scientific Basis for Friction Ridge Skin Comparisons as a Means of Identification: Committee Findings and Recommendations https://archives.fbi.gov/ archives/about-us/lab/forensic-science-communications/fsc/jan2006/ research/2006_01_research02.htm accessed 25 January 2019

Connors et al 1996 https://www.ncjrs.gov/pdffiles/dnaevid.pdf Connors E 1996 et al Convicted by Juries, Exonerated by Science: Case Studies in the Use of DNA Evidence to Establish Innocence after Trial Research Report by the National Institute of Justice, US Department of Justice https://www.ncjrs.gov/pdffiles/dnaevid.pdf accessed 7 November 2018

Cromwell 2011 https://www.scottishlawreports.org.uk/publications/ macfadyen-2011.html\#f71

The Honourable Thomas A Cromwell 2011 The Challenges of Scientific Evidence https://www.scottishlawreports.org.uk/publications/macfadyen2011.html accessed 5 March 2019 
Elster 2017 https://daily.jstor.org/forensic-dna-evidence-can-lead-wrongfulconvictions/

Elster N 2017 How Forensic DNA Evidence Can Lead to Wrongful Convictions https://daily.jstor.org/forensic-dna-evidence-can-lead-wrongfulconvictions/ accessed 17 February 2019

Epstein date unknown http://www-bcf.usc.edu/ usclrev/html_articles/ 075302/075302.htm

Epstein R date unknown Fingerprints Meet Daubert: The Myth of Fingerprint 'Science' is Revealed http://www-bcf.usc.edu/ usclrev/html_articles/ 075302/075302.htm accessed 11 February 2019

FBI 2015 https://www.fbi.gov/news/pressrel/press-releases/fbi-testimonyon-microscopic-hair-analysis-contained-errors-in-at-least-90-percent-ofcases-in-ongoing-review

Federal Bureau of Investigation 2015 FBI Testimony on Microscopic Hair Analysis Contained Errors in at Least 90 Percent of Cases in Ongoing Review https://www.fbi.gov/news/pressrel/press-releases/fbi-testimony-onmicroscopic-hair-analysis-contained-errors-in-at-least-90-percent-ofcases-in-ongoing-review accessed 6 March 2020

Hsu 2015 https://www.washingtonpost.com/local/crime/fbi-overstatedforensic-hair-matches-in-nearly-all-criminal-trials-for-decades/2015/ 04/18/39c8d8c6-e515-11e4-b510-962fcfabc310_story.html?noredirect=on \&utm_term=.c22d03885a0e Hsu SS 2015 FBI Admits Flaws in Hair Analysis over Decades https://www.washingtonpost.com/local/crime/fbi-overstated-forensic-hairmatches-in-nearly-all-criminal-trials-for-decades/2015/04/18/39c8d8c6e515-11e4-b510-962fcfabc310_story.html?noredirect=on\&utm_term=. c22d03885a0e accessed 28 March 2019

Kadane date unknown https://pdfs.semanticscholar.org/7925/ 4e4ec0ecc46ab24e14da0788dab8028107b1.pdf

Kadane $J$ date unknown Fingerprint Science https://pdfs. semanticscholar.org/7925/4e4ec0ecc46ab24e14da0788dab8028107b1.pd f accessed 13 March 2019

Kaye 2015 http://for-sci-law.blogspot.com/2015/11/marching-towardimproved-latent.html

Kaye DH 2015 Marching toward Improved Latent Fingerprint Testimony at the Army's Defence Forensic Science Centre http://for-sci- 
law.blogspot.com/2015/11/marching-toward-improved-latent.html accessed 13 February 2019

Kaye et al $2012 \mathrm{https}: / / c o m m o n s . e r a u . e d u / p u b l i c a t i o n / 1222 /$

Kaye DH et al 2012 Latent Print Examination and Human Factors: Improving the Practice through a Systems Approach. The Report of the Expert Working Group on Human Factors in Latent Print Analysis https://commons.erau.edu/publication/1222/ accessed 6 March 2020

Mnookin 2003 https://issues.org/mnookin/

Mnookin JL "Fingerprint: Not a Gold Standard" 2003 Issues in Science and Technology https://issues.org/mnookin/ accessed 11 February 2019

Mnookin 2018 https://ssrn.com/abstract=3300354

Mnookin JL 2018 The Uncertain Future of Forensic Science https://ssrn.com/abstract=3300354 accessed 3 May 2019

National Forensic Science Technology Center date unknown http://www.forensicsciencesimplified.org/prints/Fingerprints.pdf National Forensic Science Technology Center date unknown A Simple Guide to Fingerprint Analysis http://www.forensicscience simplified.org/prints/Fingerprints.pdf accessed 27 November 2018

PCAST 2016 https://obamawhitehouse.archives.gov/sites/default/files/ microsites/ostp/PCAST/pcast_forensic_science_report_final.pdf President's Council of Advisors on Science and Technology 2016 Report to the President, Forensic Science in Criminal Courts: Ensuring Scientific Validity of Feature-Comparison Methods https://obamawhite house.archives.gov/sites/default/files/microsites/ostp/PCAST/pcast_forens ic_science_report_final.pdf accessed 2 November 2018

Raphaely 2018 https://www.dailymaverick.co.za/article/2018-10-02-gettingit-wrong-guilty-until-proven-innocent/

Raphaely C 2018 Getting it Wrong - Guilty until Proven Innocent https://www.dailymaverick.co.za/article/2018-10-02-getting-it-wrong-guiltyuntil-proven-innocent/ accessed 16 November 2018

Rea 2017 https://www.cmu.edu/dietrich/news/news-stories/2017/ february/fingerprint-science.html

Rea S 2017 Fingerprint Evidence is Circumstantial, Not an Identification https://www.cmu.edu/dietrich/news/news-stories/2017/february/fingerprintscience.html accessed 4 March 2020 
Schwartz 2008 https://www.wispd.org/images/practice-groups/homicide/ ChallengingFirearmsldentificationpart2.pdf Schwartz A 2008 Challenging Firearms and Toolmark Identification: Part Two https://www.wispd.org/images/practice-groups/homicide/Challenging Firearmsldentificationpart2.pdf accessed 6 March 2020

US Department of Justice 2006 https://www.hsdl.org/? abstract\&did $=458960$

United States Department of Justice, Office of the Inspector General 2006 A Review of the FBl's Handling of the Brandon Mayfield Case https://www.hsdl.org/?abstract\&did=458960 accessed 28 January 2018

US Innocence Project date unknown https://www.innocenceproject.org/ causes/misapplication-forensic-science/

United States Innocence Project date unknown Misapplication of Forensic Science https://www.innocenceproject.org/causes/misapplication-forensicscience/ accessed 16 November 2018

US Innocence Project 2016 https://www.innocenceproject.org/wpcontent/ uploads/2016/02/DNA_Exonerations_Forensic_Science.pdf

United State Innocence Project 2016 Wrongful Convictions Involving Unvalidated or Improper Forensic Science that were Later Overturned Through DNA Testing https://www.innocenceproject.org/wpcontent/ uploads/2016/02/DNA_Exonerations_Forensic_Science.pdf accessed 16 November 2018

\section{List of Abbreviations}

ACE-V

ACHPR

AFTE Journal

Alb L Rev

Am U Int'I L Rev

Brook L Rev

Buff Pub Int LJ

Colum L Rev

DFSC

DNA

FBI

Ga St UL Rev Golden Gate UL Rev Hastings LJ
Analysis, Comparison, Evaluation and Verification

African Charter on Human and Peoples' Rights

Association of Firearm and Tool Mark Examiners Journal

Albany Law Review

American University International Review

Brooklyn Law Review

Buffalo Public Interest Law Journal

Columbia Law Review

Defence Forensic Science Centre

Deoxyribonucleic acid

Federal Bureau of Investigation

Georgia State University Law Review

Golden Gate University Law Review

Hastings Law Journal 
IAFIS

ICCPR

J Crim L \& Criminology

JLB

Jurimetrics $\mathrm{J}$

NAS

Natl Inst Justice J

NRE

PCAST

SACJ

SALJ

Tulsa L Rev

US

Va L Rev

Vand L Rev

Yale J Int'I L
Automated Fingerprint Identification System International Covenant on Civil and Political Rights

Journal of Criminal Law and Criminology Journal of Law and the Biosciences Jurimetrics Journal

National Academy of Sciences

National Institute of Justice Journal

National Registry of Exonerations

President's Council of Advisors on Science and Technology

South African Journal of Criminal Justice

South African Law Journal

Tulsa Law Review

United States

Virginia Law Review

Vanderbilt Law Review

Yale Journal of International Law 